Wicaksono, F.Y. • A.W. Irwan · A. Wahyudin - L. W. Setianingrum

\title{
Pertumbuhan dan hasil gandum (Triticum aestivum L.) yang diberi asam salisilat dan kalsium klorida dengan selang waktu yang berbeda di dataran medium Jatinangor
}

\section{Growth and yield of wheat that were treated salicylic acid and calcium chloride with different time intervals on medium land Jatinangor}

Diterima : 15 September 2015/Disetujui : 15 Oktober 2015 / Dipublikasikan : Oktober 2015

CDepartment of Crop Science, Padjadjaran University

\begin{abstract}
The objective of the research was to determine growth, yield, and quality of yield of wheat that were planted on medium land Jatinangor which were treated calcium chloride and salicylic acid with the best interval time aplication.The experiment was conducted from March until July 2015 at The Experimental Station of Faculty of Agriculture, University of Padjadjaran, Jatinangor with an altitude of about 750 metres above sea level. The experimental design used was Randomized Block Design which consisted of 5 treatments and replicated four times, there were $\mathrm{A}=3$ days interval of application of salicylic acid and calcium chloride, B = 6 days interval of application of salicylic acid and calcium chloride, $\mathrm{C}=9$ days interval of application of salicylic acid and calcium chloride, $\mathrm{D}=12$ days interval of application of salicylic acid and calcium chloride, and $\mathrm{E}=15$ days interval of application of salicylic acid and calcium chloride. Differences in the average value of the treatment was tested by Duncan Multiple Range Test at $5 \%$ significance level. Graph among treatments was tested by parallel line regression test (Chow Test at $5 \%$ significance level).The results of this research showed that there were significant different that gived by one or more treatments on growth (number of tiller, chlorophyll content, and leaf area index), yield (number of productive tiller, length of panicle, and grain weight.The best interval time application of salicylic acid and calcium chloride was 9 days.
\end{abstract}

Keywords: Wheat · Calcium chloride · Salicylic acid

Dikomunikasikan oleh T, Nurmala

Wicaksono, F.Y. ${ }^{1}$. A.W. Irwan ${ }^{1}$. A. Wahyudin ${ }^{1}$. L. W.

Setianingrum ${ }^{2}$

1 Dept. Budadaya Pertanian Fakultas Pertanian Unpad

2 Alumni Program Sarjana Agroteknologi Unpad

Korespondensi: fywicaksono@yahoo.com
Sari Penelitian ini bertujuan untuk mengetahui pertumbuhan, hasil, dan kualitas hasil tanaman gandum yang maksimum di dataran medium melalui pemberian kalsium klorida dan asam salisilat dengan interval waktu yang terbaik. Percobaan dilakukan sejak Maret hingga Juli 2015 di Kebun Percobaan Fakultas Pertanian Universitas Padjadjaran, Jatinangor, dengan ketinggian tempat yaitu $\pm 750 \mathrm{~m}$ di atas permukaan laut. Rancangan percobaan adalah Rancangan Acak Kelompok yang terdiri dari lima perlakuan dan diulang empat kali sehingga terdapat 20 plot percobaan. Ukuran petak percobaan yang digunakan adalah $3 \mathrm{~m} \times 4 \mathrm{~m}$. Adapun perlakuan yang diberikan adalah $\mathrm{A}=$ Aplikasi $\mathrm{CaCl}_{2}$ dan Asam Salisilat dengan interval waktu 3 hari, $\mathrm{B}=$ Aplikasi $\mathrm{CaCl}_{2}$ dan Asam Salisilat dengan interval waktu 6 hari, $\mathrm{C}=$ Aplikasi $\mathrm{CaCl}_{2}$ dan Asam Salisilat dengan interval waktu 9 hari, $\mathrm{D}=$ Aplikasi $\mathrm{CaCl}_{2}$ dan Asam Salisilat dengan interval waktu 12 hari, dan $\mathrm{E}=$ Aplikasi $\mathrm{CaCl}_{2}$ dan Asam Salisilat dengan interval waktu 15 hari.Perbedaan nilai rata-rata perlakuan diuji dengan Duncan Multiple Range Test pada taraf nyata $5 \%$. Grafik antar perlakuan dibandingkan dengan uji kesejajaran dan keberimpitan garis regresi (uji Chow pada taraf nyata $5 \%$ ). Hasil penelitian menunjukkan bahwa terdapat perbe-daan yang nyata yang diberikan salah satu perlakuan terhadap komponen pertumbuhan (jumlah anakan, kandungan klorofil, dan indeks luas daun), komponen hasil (jumlah malai, panjang malai, gabah isi, bobot biji per malai, dan bobot biji per tanaman). Pemberian asam salisilat dan kalsium klorida memberikan pertumbuhan dan hasil tanaman gandum terbaik pada interval 9 hari.

Kata kunci : Gandum · Asam salisilat · Kalsium klorida 


\section{Pendahuluan}

Tanaman gandum merupakan tanaman pangan utama sebagai penghasil bahan baku industri terigu dan turunannya. Terigu merupakan makanan pokok kedua setelah beras di Indonesia. Konsumsinya pada tahun 2013 mencapai 5,4 juta metrik ton. Kebutuhan gandum yang begitu besar disuplai dengan impor gandum sebesar 6,7 juta metrik ton yang menjadikan Indonesia sebagai importir gandum terbesar ke4 dunia setelah Mesir, Cina, dan Brazil (Aptindo, 2014). Produksi gandum dalam negeri harus ditingkatkan agar dapat mengurangi ketergantungan impor gandum.

Indonesia yang memiliki iklim tropis terbatas dalam memproduksi gandum yang berasal dari daerah subtropis. Tanaman gandum memiliki adaptasi yang baik di daerah tropis bila ditanam di dataran tinggi yang memiliki suhu rendah, namun kesulitan bersaing dengan komoditas hortikultura yang sebelumnya telah biasa dibudidayakan. Dataran medium, yaitu dataran dengan ketinggian 500-900 m dpl, sangat potensial untuk budidaya gandum karena mempunyai luas lahan pertanian yang lebih luas dibandingkan dataran tinggi. penanaman gandum di lahan kering dataran medium mempunyai permasalahan dimana suhu lebih tinggi sehingga produksi gandum tidak optimal bahkan tanaman dapat terkena stress.

Panas, kekeringan, dan kekurangan unsur hara merupakan cekaman utama yang membatasi produksi tanaman (Rawson, 1988; Entez and Flower, 1990). Kisaran suhu optimum untuk mendapatkan berat biji gandum yang maksimum adalah $15-18{ }^{\circ} \mathrm{C}$. Temperatur yang lebih tinggi (18$30{ }^{\circ} \mathrm{C}$ ) mengurangi lamanya pengisian biji dan pengurangan ini tidak dibarengi dengan peningkatan akumulasi asimilat. Akibatnya, hasil gandum akan rendah (Wardlaw et al., 1989; Stone et al., 1995). Menurut Schlehuber dan Tucker (1967) dikutip Tati Nurmala (1980), perakaran bibit gandum tumbuh paling lebat pada suhu tanah antara $12-16^{\circ} \mathrm{C}$. Pada suhu tanah yang lebih tinggi, plumula lebih dahulu keluar daripada akar kecambah sehingga pertumbuhan akar agak terhambat. Pertumbuhan akar yang terhambat menyebabkan penyerapan hara tidak optimal sehingga fotosintesis dan pertumbuhan tanaman tidak optimal.

Aplikasi zat pengatur tumbuh, yaitu kalsium klorida dan asam salisilat, dapat mengurangi dampak cekaman panas pada tanaman gandum.
Wicaksono (2013) melaporkan bahwa hasil tanaman gandum terbaik diberikan oleh perlakuan aplikasi kalsium klorida $2 \times 10^{-2} \mathrm{M}$ dan asam salisilat $1,3 \times 10^{-4} \quad$ M. Peningkatan konsentrasi kalsium klorida sampai $10^{-2} \mathrm{M}$ menaikkan indeks luas daun, volume akar, kandungan klorofil, bobot malai, bobot biji, dan hasil pada taraf konsentrasi asam salisilat $0 \mathrm{M}$.

Penelitian Jiang dan Huang (2000) menyatakan bahwa kalsium $\left(\mathrm{Ca}^{2+}\right)$ terlibat dalam toleransi tanaman terhadap cekaman panas dengan mengatur metabolisme antioksidan dan air. Kalsium juga berperan mengatur turgor selpenjaga dan mengurangi peroksidasi lipid membran sel ketika tanaman mengalami cekaman panas. Senyawa lain yang terlibat dalam tanggapan tanaman terhadap cekaman panas adalah asam salisilat. Asam salisilat merupakan komponen penting dari jalur sinyal dalam respons terhadap resistensi sistemik dan reaksi hipersensitif (Kawano et al., 1998). Pemberian asam salisilat menurunkan thiobar-bituric acid-reactive substances (TBARS) dan kebocoran elektrolit relatif (REL) pada cekaman panas atau dingin. TBARS dan REL merupakan akibat dari peroksidasi lipida yang menyebab-kan rusaknya kloroplas dan membran sel. Penurunan TBARS dan REL menunjukkan bahwa asam salisilat dapat menginduksi toleransi panas atau dingin. $\mathrm{Ca}^{2+}$ sitosol dalam sel mesofil juga menjadi meningkat setelah diberi perlakuan asam salisilat (Wang dan Li, 2005). Meskipun demikian, interval waktu pemberian kalsium klorida dan asam salisilat untuk meningkatkan pertumbuhan dan hasil tanaman gandum belum diketahui dari penelitian-penelitian yang lain.

Masalah yang dapat diidentifikasi dalam penelitian ini adalah apakah ada interval waktu yang tepat dalam pemberian kalsium klorida dan asam salisilat yang memberikan pertumbuhan, hasil,dan kualitas hasil tanaman gandum yang terbaik di dataran medium. Pengujian kalsium klorida dan asam salisilat perlu dilakukan untuk mengetahui pertumbuhan, hasil, dan kualitas hasil tanaman gandum yang maksimum di dataran medium melalui pemberian kalsium klorida dan asam salisilat dengan interval waktu yang terbaik. Manfaat penelitian ini adalah mengembangkan sains mengenai adaptasi tanaman gandum di dataran medium dengan beberapa rekayasa ekofisiologi.

Berdasarkan kerangka pemikiran, dapat dirumuskan hipotesis yaitu "hasil dan kualitas tanaman gandum yang optimal pada kondisi panas di dataran medium dapat diperoleh 
dengan pemberian kalsium klorida dan asam salisilat dalam selang waktu tertentu".

\section{Bahan dan Metode}

Penelitian ini dilaksanakan di Kebun Percobaan Fakultas Pertanian Universitas Padjadjaran, Jatinangor, Kabupaten Sumedang, Jawa Barat. Ketinggian tempat lokasi penelitian sekitar 750 $\mathrm{m}$ di atas permukaan laut $(\mathrm{dpl})$, dengan tipe iklim C3 menurut klasifikasi Oldeman. Suhu rata-rata sekitar $23,8{ }^{\circ} \mathrm{C}$. Jenis tanah di areal penelitian adalah Inseptisol dengan $\mathrm{pH}$ tanah 5,83 . Penelitian dilaksanakan mulai Maret sampai dengan Juli 2015.

Bahan yang akan digunakan dalam penelitian ini adalah benih gandum Kultivar Dewata yang diproduksi oleh laboratorium Produksi Tanaman Faperta Unpad pada musim tanam 2014, kalsium klorida, dan asam salisilat, pupuk majemuk NPK (15-15-15), pupuk urea $(45 \% \mathrm{~N})$, dan insektisida awal tanam yang mengandung bahan aktif karbofuran. Bahan pendukung yang lain adalah bahan untuk analisis kadar gluten, kadar protein, dan analisis tanah lengkap.

Peralatan budidaya yang dibutuhkan mulai dari persiapan lahan hingga panen adalah cangkul, kored, tugal, ember, tali, karung plastik dan peralatan penunjang lainnya. Selain itu juga digunakan beberapa peralatan pengamatan di lapang, peralatan dokumentasi, oven, timbangan, dan komputer. Sarana lain yang digunakan adalah peralatan laboratorium untuk analisis tanah dan peralatan laboratorium pascapanen untuk menganalisis kadar protein dan kadar gluten.

Penelitian ini menggunakan metode eksperimental yang akan dilakukan dalam lingkungan tidak terkendali. Rancangan percobaan adalah Rancangan Acak Kelompok yang terdiri dari lima perlakuan dan diulang empat kali sehingga terdapat 20 plot percobaan. Ukuran petak percobaan yang digunakan adalah $3 \times 4 \mathrm{~m}$. Adapun perlakuan yang diberikan adalah $\mathrm{A}=$ Aplikasi $\mathrm{CaCl}_{2}$ dan asam salisilat dengan interval waktu 3 hari, $\mathrm{B}=$ Aplikasi $\mathrm{CaCl}_{2}$ dan ssam salisilat dengan interval waktu 6 hari, $\mathrm{C}=$ Aplikasi $\mathrm{CaCl}_{2}$ dan ssam salisilat dengan interval waktu 9 hari, $\mathrm{D}=$ Aplikasi $\mathrm{CaCl}_{2}$ dan asam salisilat dengan interval waktu 12 hari, dan $\mathrm{E}=$ Aplikasi $\mathrm{CaCl}_{2}$ dan asam salisilat dengan interval waktu 15 hari.

Aplikasi kalsium klorida dan asam salisilat dengan cara disemprot menggunakan knapsack sprayer. Konsentrasi kalsium klorida yang digunakan adalah $2 \times 10^{-2} \mathrm{M}$ sedangkan konsentrasi asam salisilat yang digunakan adalah $7 \times 10^{-5} \mathrm{M}$. Volume semprot yang digunakan untuk penyemprotan bergantung pada luas kanopi tanaman, berkisar antara 0,6-1 L larutan per petak percobaan.

Pengamatan penunjang dilakukan untuk mengetahui suhu, kelembaban, dan curah hujan selama percobaan, juga umur panen dan umur berbunga tanaman. Pengamatan utama dilakukan untuk mengetahui komponen pertumbuhan, komponen hasil, hasil, dan kualitas hasil. Komponen pertumbuhan meliputi tinggi tanaman, jumlah anakan, kandungan klorofil, dan indeks luas daun. Komponen hasil meliputi jumlah malai, panjang malai, jumlah biji per malai, jumlah gabah isi, jumlah gabah hampa, bobot 100 biji, dan bobot biji per malai. Pengamatan hasil dilakukan pada bobot biji per tanaman. Kualitas hasil meliputi ukuran biji, kadar protein, kadar gluten, dan rendemen tepung.

Uji statistik yang digunakan untuk mengetahui minimal sepasang perlakuan yang berbeda nyata adalah sidik ragam univariate pada taraf $5 \%$. Untuk menguji perbedaan nilai rata-rata perlakuan digunakan Duncan Multiple Range Test pada taraf nyata $5 \%$ (Gasperz, 1995). Untuk membandingkan grafik antar perlakuan dilakukan uji kesejajaran dan keberimpitan garis regresi.

\section{Hasil dan Pembahasan}

Berdasarkan pengamatan penunjang, kisaran suhu rata-rata selama percobaan adalah 21,9$23,4{ }^{\circ} \mathrm{C}$. Suhu selama percobaan melebihi suhu optimal tanaman gandum untuk pertumbuhan dan hasil tanaman gandum. Suhu yang tinggi disebutkan dapat mengurangi lamanya pengisian biji dan mengurangi berat biji (Wardlaw et al., 1989; Stone et al., 1995). Kelembaban selama percobaan berkisar antara 82-90 \%, sesuai dengan syarat tumbuh tanaman gandum. Curah hujan selama fase vegetatif ( $0-82 \mathrm{hst})$ berkisar antara 227,5-400,5 mm/bulan, sedangkan fase generatif (82-129 hst) berkisar antara 1,7-7,4 $\mathrm{mm} /$ bulan. Kekurangan air selama fase generatif disuplai dari penyiraman.

Umur berbunga tanaman mencapai 82 hari, sedangkan umur panen adalah 129 hari. Umur berbunga dan umur panen tanaman gandum pada deskripsi varietas di dataran tinggi masing-masing adalah 82 hari dan 129 hari. Umur berbunga dan 
umur panen tanaman pada dataran medium sama dengan umur tanaman pada deskripsi varietas di dataran tinggi. Hal ini disebabkan tanaman diberi hormon gibberellin yang menghambat terjadinya penuaan (Salisbury dan Ross, 1995).

Tinggi tanaman dari umur 3-8 mst menunjukkan tidak ada perbedaan yang nyata berdasarkan uji kesejajaran dan keberimpitan garis regresi. Grafik tinggi tanaman dapat dilihat pada Gambar 1.

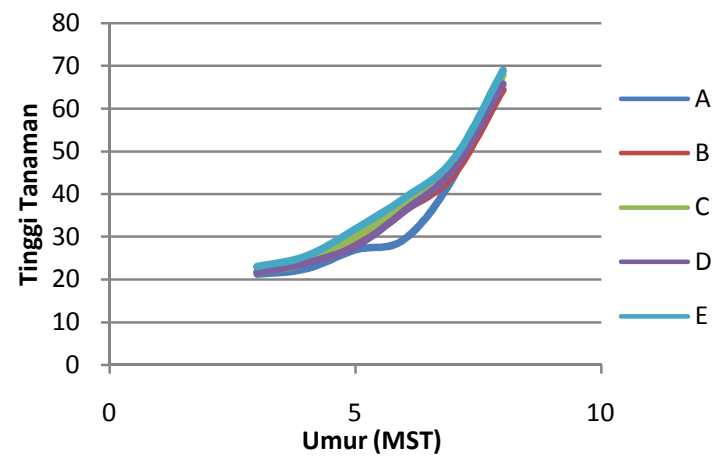

Keterangan:

Persamaan garis regresi

$\begin{array}{ll}\text { A } & y=0.712 x^{3}-4.64 x^{2}+11.438 x+13.560\left(r^{2}=0.997\right) \\ \text { B } & y=0.349 x^{3}-1.763 x^{2}+5.604 x+18.411\left(r^{2}=0.997\right) \\ \text { C } & y=0.414 x^{3}-2.409 x^{2}+8.288 x+14.925\left(r^{2}=0.996\right) \\ \text { D } & y=0.308 x^{3}-1.239 x^{2}+4.207 x+18.310\left(r^{2}=0.998\right) \\ \text { E } & y=0.376 x^{3}-2.125 x^{2}+7.882 x+16.542\left(r^{2}=0.996\right)\end{array}$

Matriks uji garis

Matriks uji garis
\begin{tabular}{|c|c|c|c|c|}
\hline & B & C & D & E \\
\hline A & $/$ & $/$ & $/$ & $/$ \\
\hline B & & $/$ & $/$ & $/$ \\
\hline C & & & $/$ & $/$ \\
\hline D & & & & $/$ \\
\hline
\end{tabular}

/: kedua garis sejajar atau berimpit

\section{Gambar 1. Grafik Tinggi Tanaman Gandum.}

Tinggi tanaman dipengaruhi oleh genetik tanaman dan lingkungan (Gardner et al., 1995). Perbedaan tinggi yang tidak berbeda nyata antar perlakuan kemungkinan akibat tinggi lebih banyak dipengaruhi oleh genetik tanaman.

Pemberian asam salisilat dan kalsium klorida dengan selang waktu 9 hari memberikan jumlah anakan yang lebih banyak dibandingkan dengan perlakuan yang lain berdasarkan uji kesejajaran dan keberimpitan garis regresi. Pengaruh selang waktu pemberian asam salisilat dan kalsium klorida terhadap jumlah anakan dapat dilihat pada grafik di Gambar 2.

Pemberian asam salisilat dan kalsium klorida dalam interval waktu 9 hari memberikan jumlah anakan yang lebih banyak karena asam salisilat dan kalsium klorida mencegah kerusakan sel akibat panas dan pertumbuhan akar menjadi tidak terhambat. Jumlah anakan selama fase vegetatif dipengaruhi oleh penyerapan unsur hara. Pemberian asam salisilat dan kalsium klorida dengan interval 9 hari dapat memberikan hingga 10 anakan.Sebagai perbandingan, jumlah anakan optimum bagi gandum subtropis adalah 10 anakan atau lebih (Stapper, 2007). Pada grafik jumlah anakan, terlihat pelandaian penambahan jumlah anakan antara 4-6 mst. Hal ini disebabkan adanya cekaman panas yang menyebabkan pertumbuhan tanaman terhambat.

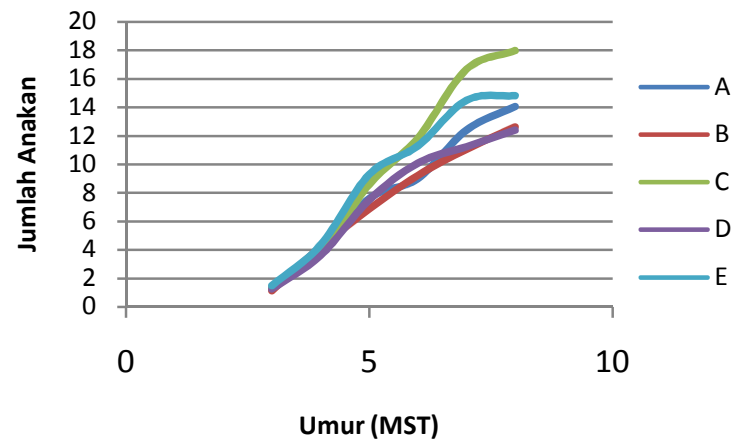

Keterangan:

Persamaan garis regresi

A $y=-0.00313 x^{4}+0.0257 x^{3}-0.120 x^{2}+3.109 x-1.725\left(r^{2}=0.991\right)$

B $\quad y=0.004 x^{4}-0.0565 x^{3}+0.0806 x^{2}+3.124 x-1.999\left(r^{2}=0.999\right)$

C $\mathrm{y}=-0.027 \mathrm{x}^{4}+0.193 \mathrm{x}^{3}+0.0388 \mathrm{x}^{2}+1.745 \mathrm{x}-0.610\left(\mathrm{r}^{2}=0.996\right)$

D $y=0.089 x^{4}-1.322 x^{3}+6.431 x^{2}-8.995 x+5.042\left(r^{2}=0.999\right)$

E $y=0.0203 x^{4}-0.399 x^{3}+2.213 x^{2}-0.882 x+0.479\left(r^{2}=0.992\right)$

Matriks uji garis

\begin{tabular}{|l|l|l|l|l|}
\hline & B & C & D & E \\
\hline A & X & X & X & X \\
\hline B & & X & X & X \\
\hline C & & & X & X \\
\hline D & & & & X \\
\hline
\end{tabular}

$\mathrm{X}$ : kedua garis berpotongan

\section{Gambar 2. Jumlah Anakan Tanaman Gandum.}

Pemberian asam salisilat dan kalsium klorida dengan selang waktu 9 hari memberikan kandungan klorofil yang lebih banyak dibandingkan dengan perlakuan yang lain berdasarkan uji kesejajaran dan keberimpitan garis regresi. Pengaruh selang waktu pemberian asam salisilat dan kalsium klorida terhadap kan-dungan klorofil dapat dilihat pada grafik di Gambar 3.

Penelitian Wicaksono et. al. (2013) menyebutkan bahwa penambahan kalsium klorida dan asam salisilat pada konsentrasi tertentu dapat meningkatkan jumlah klorofil. konsentrasi asam 
salisilat pada setiap taraf kalsium klorida dapat terjadi karena asam salisilat meningkatkan $\mathrm{Ca}^{2+}$ sitosol dalam sel mesofil. Kenaikan tingkat $\mathrm{Ca}^{2+}$ sitoplasma sebagai respons terhadap sinyalbisa disebabkan masuknya $\mathrm{Ca}^{2+}$ dari apoplas atau $\mathrm{Ca}^{2+}$ dihasilkan dari penyimpanan intraseluler seperti ER, vakuola, mitokondria, kloroplas, dan inti. Setelah daun diberi perlakuan asam salisilat, sejumlah besar partikel $\mathrm{Ca}^{2+}$ berada di sisi bagian dalam membran plasma, tetapisedikit berada di ruang antar sel dan vakuola. Hal inimenunjukkan bahwa perlakuan asam salisilat meningkatkan $\mathrm{Ca}^{2+}$ dalam sitoplasma yang berasal dari dalam vakuola atau ruang antar sel (Wang dan Li, 2005). Sebagian besar kandungan klorofil mengalami pelandaian antara 4-5 mst. Hal ini disebabkan adanya cekaman panas yang menyebabkan pertumbuhan terhambat.

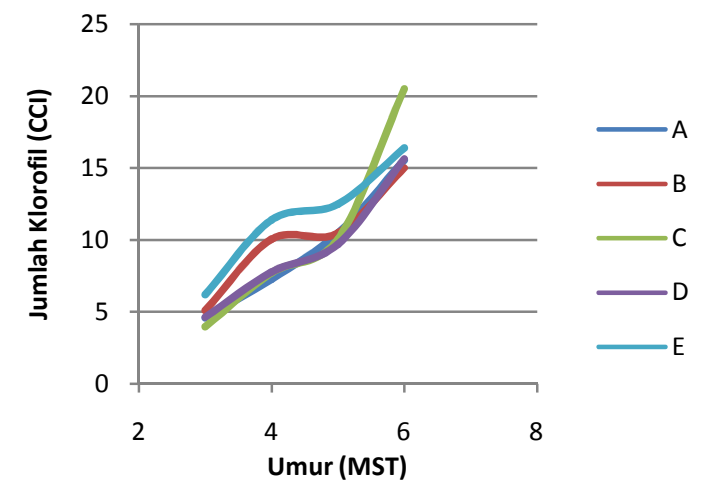

Keterangan:

Persamaan garis regresi

A $\quad \mathrm{y}=0.597 \mathrm{x}^{2}+0.627 \mathrm{x}+3.432\left(\mathrm{r}^{2}=0.999\right)$

B $\quad y=-0.111 x^{2}+3.577 x+2.053\left(r^{2}=0.925\right)$

C $\quad \mathrm{y}=1.674 \mathrm{x}^{2}-3.162 \mathrm{x}+5.919\left(\mathrm{r}^{2}=0.971\right)$

D $\quad \mathrm{y}=0.697 \mathrm{x}^{2}+0.0098 \mathrm{x}+4.180\left(\mathrm{r}^{2}=0.979\right)$

E $\quad y=-0.320 x^{2}+4.762 x+2.110\left(r^{2}=0.954\right)$

Matriks uji garis

\begin{tabular}{|l|l|l|l|l|}
\hline & B & C & D & E \\
\hline A & I & X & / & X \\
\hline B & & X & / & / \\
\hline C & & & X & X \\
\hline D & & & & X \\
\hline
\end{tabular}

$\mathrm{X}$ : kedua garis berpotongan,

/: kedua garis sejajar atau berimpit

\section{Gambar 3. Grafik Jumlah Klorofil.}

Indeks luas daun tanaman yang diberi perlakuan asam salisilat dan kalsium klorida di minggu ke-6 dapat dilihat pada Tabel 1. Indeks luas daun yang diberi perlakuan asam salisilat dan kalsium klorida dengan interval 9 hari tidak berbeda nyata dengan perlakuan interval 12 hari, tetapi lebih tinggi dibandingkan dengan perlakuan yang lain.
Tabel 1. Indeks Luas Daun Tanaman pada Minggu Ke-6.

\begin{tabular}{lrl}
\hline \hline Perlakuan & Indeks Luas Daun \\
\hline A (interval 3 hari) & $2,89 \mathrm{a}$ \\
B (interval 6 hari) & $3,19 \mathrm{a}$ \\
C (interval 9 hari) & $4,00 \mathrm{~b}$ \\
D (interval 12 hari) & $3,26 \mathrm{ab}$ \\
E (interval 15 hari) & $2,70 \mathrm{a}$ \\
\hline \hline
\end{tabular}

Keterangan: angka-angka yang diikuti huruf yang sama menunjukkan tidak berbeda nyata menurut uji jarak berganda Duncan pada taraf kepercayaan $95 \%$.

Daun merupakan organ tempat fotosintesis yang dipengaruhi oleh cekaman suhu. Kloroplas pada daun gandum dapat rusak oleh cekaman suhu, terutama pada bagian fotosistem II (AlKhatib dan Paulsen, 1999). Kemampuan fotosintesis diantaranya ditentukan oleh luas daun. Semakin besar luas daun maka semakin banyak kandungan kloroplas.Aplikasi asam salisilat dan kalsium klorida terbukti meningkatkan kadar $\mathrm{Ca}^{2+}$ di dalam sitosol. Konsentrasi $\mathrm{Ca}^{2+}$ yang cukup di sitosol dapat mengurangi efek cekaman panas dengan cara mempertahankan aktivitas antioksidan dan mengurangi peroksidasi lipid membran kloroplas (Jiang dan Huang, 2000).

Kalsium juga berperan dalam menjaga potensial turgor sel penjaga dan aparatur stomata dimana cekaman dapat dikurangi akibat pengaturan potensial zat terlarut (Hare et. al., 1998 dalam Jiang dan Huang, 2000). Potensial zat terlarut akan berkurang bila konsentrasi $\mathrm{Ca}^{2+}$ dalam sel semakin besar sehingga menurunkan potensial air sel.

Komponen hasil dan hasil tanaman disajikan pada Tabel 2. Pada pengamatan jumlah malai, panjang malai, gabah isi, bobot biji per malai, dan bobot biji per tanaman menunjukkan adanya perlakuan yang menyebabkan perbedaan yang nyata pada komponen hasil tersebut. Pada pengamatan bobot 100 butir, tidak ada perlakuan yang menyebabkan perbedaan yang nyata.

Pada pengamatan jumlah malai, perlakuan asam salisilat dan kalsium klorida dengan inter-val 6 hari tidak berbeda nyata dengan interval 9 hari, tetapi berbeda nyata dengan perlakuan lainnya. Jumlah anakan yang dibentuk selama fase vegetatif tidak menjamin semua anakan tersebut memproduksi malai. Produksi malai dipengaruhi oleh banyak hal, terutama penyerapan unsur hara yang dibutuhkan untuk membentuk malai. Pemberian asam salisilat dan kalsium klorida yang terlalu sering mungkin menyebabkan keracunan, terutama untuk unsur $\mathrm{Ca}$ dan $\mathrm{Cl}$. 
Tabel 2. Komponen Hasil dan Hasil Tanaman.

\begin{tabular}{lcccccc}
\hline \hline Perlakuan & $\begin{array}{c}\text { Jumlah } \\
\text { Malai }\end{array}$ & $\begin{array}{c}\text { Panjang } \\
\text { Malai }(\mathrm{cm})\end{array}$ & $\begin{array}{c}\text { Jumlah } \\
\text { Gabah Isi }\end{array}$ & $\begin{array}{c}\text { Bobot 100 } \\
\text { butir }(\mathrm{g})\end{array}$ & $\begin{array}{c}\text { Bobot biji per } \\
\text { malai }(\mathrm{g})\end{array}$ & $\begin{array}{c}\text { Bobot biji per } \\
\text { tanaman }(\mathrm{g})\end{array}$ \\
\hline A (interval 3 hari) & $10,075 \mathrm{ab}$ & $10,9 \mathrm{ab}$ & $85,52 \mathrm{~b}$ & $3,01 \mathrm{a}$ & $0,31 \mathrm{~b}$ & $2,76 \mathrm{bc}$ \\
B (interval 6 hari) & $9,525 \mathrm{a}$ & $9,3 \mathrm{a}$ & $85,57 \mathrm{~b}$ & $3,13 \mathrm{a}$ & $0,30 \mathrm{~b}$ & $2,64 \mathrm{bc}$ \\
C (interval 9 hari) & $12,588 \mathrm{~b}$ & $10,1 \mathrm{ab}$ & $116,96 \mathrm{c}$ & $3,01 \mathrm{a}$ & $0,34 \mathrm{~b}$ & $3,25 \mathrm{c}$ \\
D (interval 12 hari) & $10,275 \mathrm{ab}$ & $11,5 \mathrm{~b}$ & $56,51 \mathrm{a}$ & $3,13 \mathrm{a}$ & $0,25 \mathrm{ab}$ & $1,83 \mathrm{a}$ \\
E (interval 15 hari) & $11,675 \mathrm{ab}$ & $11,4 \mathrm{~b}$ & $61,35 \mathrm{a}$ & $3,09 \mathrm{a}$ & $0,18 \mathrm{a}$ & $1,80 \mathrm{a}$ \\
\hline \hline
\end{tabular}

Keterangan: angka-angka yang diikuti huruf yang sama menunjukkan tidak berbeda nyata menurut uji jarak berganda Duncan pada taraf kepercayaan $95 \%$.

Tabel 3. Pengamatan Kualitas Hasil.

\begin{tabular}{lcc}
\hline \hline Perlakuan & Rendemen Tepung (\%) & Kadar Gluten (\%) \\
\hline A (interval 3 hari) & $0,985 \mathrm{a}$ & $7,719 \mathrm{a}$ \\
B (interval 6 hari) & $0,972 \mathrm{a}$ & $7,952 \mathrm{a}$ \\
C (interval 9 hari) & $0,983 \mathrm{a}$ & $8,005 \mathrm{a}$ \\
D (interval 12 hari) & $0,980 \mathrm{a}$ & $7,868 \mathrm{a}$ \\
E (interval 15 hari) & $0,989 \mathrm{a}$ & $8,019 \mathrm{a}$ \\
\hline \hline
\end{tabular}

Keterangan: angka-angka yang diikuti huruf yang sama menunjukkan tidak berbeda nyata menurut uji jarak berganda Duncan pada taraf kepercayaan $95 \%$.

Panjang malai merupakan komponen hasil yang mempunyai hubungan langsung dengan banyaknya floret. Semakin panjang malai maka semakin banyak pula floret yang terbentuk yang berpotensi membentuk jumlah biji yang semakin banyak (Kirby, 2002). Pemberian asam salisilat dan kalsium klorida dengan interval 12 dan 15 hari memberikan panjang malai yang berbeda nyata dengan interval 6 hari dan tanpa aplikasi kalsium klorida. Pemberian kalsium klorida dan asam salisilat yang tidak terlalu sering dapat mencegah keracunan unsur hara yang menyebabkan pembentukan malai terhambat, namun bila dilihat pada jumlah gabah isi, pengisian biji terhambat pada interval yang jarang (12 dan 15 hari), tetapi juga menurun pada interval yang terlalu sering (3 dan 6 hari). Hal yang mirip dapat ditemukan pada parameter bobot biji per malai dan bobot biji per tanaman.

Akumulasi fotosintat pada biomassa tanaman dipengaruhi oleh proses fotosintesis dan respirasi selama pertumbuhan (Salisbury dan Ross, 1995). Selama masa vegetatif, suhu tinggi dapat menyebabkan rusaknya komponen fotosintesis dan mengurangi taraf asimilasi karbondioksida. Sensitivitas fotosintesis terhadap panas merusak komponen fotosistem II yang berlokasi dalam membran tilakoid dan merusak membran kloroplas (Al-Khatib dan Paulsen, 1999). Pemberian asam salisilat dan kalsium klorida yang jarang dapat menyebabkan sel tidak tahan terhadap cekaman panas.
Pemberian asam salisilat dan kalsium klorida yang terlalu sering dapat menyebabkan keracunan unsur hara $\mathrm{Ca}$ dan $\mathrm{Cl}$. Interval pemberian asam salisilat dan kalsium klorida terbaik pada komponen hasil adalah 9 hari.

Pengamatan kualitas hasil yang dipengaruhi pemberian asam salisilat dan kalsium klorida dengan interval yang berbeda dapat dilihat pada Tabel 3.

Aplikasi kalsium klorida dan asam salisilat tidak memberikan perbedaan yang nyata terhadap rendemen tepung gandum utuh dan kadar gluten. Rendemen tepung gandum utuh ditentukan oleh efektivitas mesin penepungan (Wilson, 1955). Semakin banyak tepung yang tercecer, maka semakin rendah rendemen tepungnya.

Kadar gluten atau protein dalam gandum ditentukan oleh fotosintesis dan nutrisi tanaman, terutama nitrogen. Nitrogen merupakan penyusun asam amino dalam pembentukan protein (Salisbury dan Ross, 1995). Kadar gluten pada percobaan belum mencapai ideal.Kadar gluten ideal bagi pembuatan roti adalah 12-14 \%. Hal ini diduga karena penyerapan nitrogen terhambat karena pertumbuhan akar terhambat.

\section{Kesimpulan dan Saran}

Kesimpulan. Pemberian asam salisilat dan kalsium klorida memberikan pertumbuhan dan hasil tanaman gandum terbaik pada interval 9 hari 
Saran. Penelitian lanjutan dapat dilakukan untuk mengetahui interval waktu pemberian asam salisilat dan kalsium klorida di musim tanam yang berbeda.

\section{Ucapan Terima Kasih}

Terimakasih untuk Fakultas Pertanian Unpad yang telah membiayai penelitian ini dalam program Hibah Kompetitif Fakultas Pertanian Unpad tahun 2015

\section{Daftar Pustaka}

Al-Khatib, K. and G. M. Paulsen. 1999. Hightemperature effects on photosynthetic processes in temperate and tropical cereals. Crop Sci. 39: 119-125.

Entez, M. H., and D.B. Flower. 1990. Differential agronomic response of wheat cultivars to environmental stress. Crop Sci. 30:1119-23.

Gardner, F.P., R.B. Pearce, dan R.L. Mitchell. 1991. Fisiologi Tanaman Budidaya (Terjemahan H. Susilo). UI Press. Jakarta.

Gasperz, V. 1995. Teknik Analisis dalam Penelitian Percobaan Edisi 1. Penerbit Tarsito. Bandung.

Jiang, Y., and B. Huang. 2000. Effects of calcium on antioxidant activities and water relations associated with heat tolerance in two cool-season grass. J. of Exp. Bot. 52:341-359.

Kawano, T., N. Sahashi, K. Takahashi, N. Uozumi, S. Muto, 1998. Salicylic acid induces extracellular superoxide generation followed by an increase in cytosolic calcium ion in tobacco suspension culture: the earliest events in salicylic acid signal transduction. Plant Cell Physiol. 39:721-730.
Kirby, E. J. M. 2002. Botany of the Wheat Plant. Bread Wheat Improvement and Production. Food and Agriculture Organization of United Nation. Rome.

Rawson, H.M. 1988. Effect of high temperatures on the development and yield of wheat and practices to reduce deleterious effects.ln A.R. Klatt (Eds). Wheat production constrains in tropical environments. Mexico City: CIMMYT, 44-62.

Salisbury, F.B. dan C.W. Ross. 1995. Fisiologi Tumbuhan (Terjemahan D.R. Lukman). Penerbit ITB. Bandung.

Stapper, M. 2007. Crop Monitoring and Zadoks Growth Stages for Wheat. CSIRO Plant Industry. Canberra.

Stone, P.J., R. Savin, I.F. Wardlaw, and M.E. Nicolas. 1995. The influence of recovery temperature on the effects of brief heat shock on wheat. I. Grain growth. Aus. J. Plant Physiol., 22, 945-954.

Tati Nurmala, 1980. Budidaya Tanaman Gandum (Triticum sp.). PT. Karya Nusantara. Jakarta.

Wang, Li-Jun., and Shao-Hua Li. 2006.Salicylic acid-induced heat or cold tolerance in relation to $\mathrm{Ca} 2+$ homeostasis and antioxidant systems in young grape plants. Plant Sci., 170: 685-694

Wardlaw, I.F., I.A. Dawson and P. Munibic, 1989. The tolerance of wheat to high temperatures during reproductive growth. II. Grain development. Aus. J. Agri. Res., 40: 1-13

Wicaksono, F.Y., T. Nurmala, Sumadi. 2013. Pertumbuhan dan hasil tanaman gandum yang diberi perlakuan asam salisilat dan kalsium klorida yang diadaptasikan di dataran medium Jatinangor. J. Kultivasi 12, 8-13.

Wilson, H.K. 1955. Grain Crops. McGraw Hill Book Company, Inc. New York. 